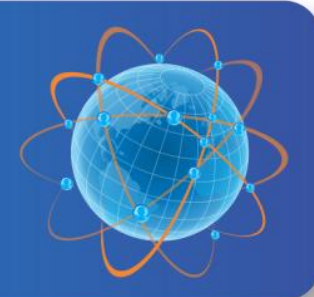

\title{
Modal Sosial Dalam Penanggulangan Bencana Banjir (Kasus di Kabupaten Bandung, Jawa Barat)
}

Authors : R.A. Tachya Muhamad, Bintarsih Sekarningrum, Yusar

Published by : Departemen of Sociology, Faculty of Social and Political Science, Universitas Padjadjaran

Accepted : March 2017; Approved : April 2017

Sosiogobal: Jurnal Pemikiran dan Penelitian Sosiologi is the Department of Sociology, Faculty of Social and Political Science, Universitas Padjadjaran flagship journal. The Sosioglobal journal founded in 2016 with the mission to publish original works of interest to the discipline of sociology in general, sociological thinking, new theoretical developments, results of research that enhance understanding of fundamental social processes, and methodological innovations. We are welcome a research article, working paper, theoretical/conceptual and methodological review to submit to our journal. In addition, we are accept relevant book review that currently publish and enrich sociological perspectives. Please submit article to http://jurnal.unpad.ac.id/sosioglobal

To cite this article :

Muhamad, Tachya, Bintarsih Sekarningrumet and Yusar.2017. Modal Sosial Dalam Penanggulangan Bencana Banjir (Kasus di Kabupaten Bandung, Jawa Barat).Sosioglobal : Jurnal Pemikiran dan Penelitian Sosiologi 1(2):101-114. 


\title{
MODAL SOSIAL DALAM PENANGGULANGAN BENCANA BANJIR (Kasus di Kabupaten Bandung, Jawa Barat)
}

\author{
R.A. Tachya Muhamad ${ }^{1}$, Bintarsih Sekarningrum ${ }^{2}$, Yusar $^{3}$ \\ Prodi Sosiologi, Fakultas Ilmu Sosial dan Ilmu Politik, Universitas Padjadjaran \\ ra.tachya@unpad.ac.id
}

\begin{abstract}
ABSTRAK
Bencana banjir seringkali terjadi di wilayah Kabupaten Bandung, Jawa Barat. Beberapa manajemen bencana banjir telah dilakukan di wilayah ini, tetapi seringkali hanya bersifat teknis seperti normalisasi sungai dan penanganan yang bersifat sosial seperti merelokasi penduduk. Tetapi berbagai upaya ini belum mampu menyelamatkan penduduk dari musibah banjir. Studi ini mengidentifikasi berbagai faktor dari kapital sosial yang ada di masyarakat yang tinggal di wilayah banjur serta menganalisa peranan LSM didalam merespon bencana banjir di Kabupaten Bandung. Studi ini menggunakan pendelatan kualitatif dengan menggunakan metode pengumpulan data wawancara, pengamatan, dan dokumentasi di tiga desa yang paling menderita akibat banjir di Kabupaten Bandung. Ketiga desa tersebut adalah Bojongsoang, Dayeuh Kolot dan Bale Endah. Hasil penelitian menunjukan bahwa terjadi penguatan kapital sosial di ketiga desa meskipun dengan karakteristik yang berbeda. Ketahanan sosial dimiliki oleh penduduk Dayeuh Kolot dan Andir dimana struktur masyarakatnya didominasi oleh kelas menengah dan berpendidikan sehingga mereka lebih independen dan responsif ketika menghadapi bencana banjir. Sementara penduduk Desa Bojongsoang relatif lebih mengalami ketergantungan ketika ketika banjir terjadi disebabkan masig banyaknya penduduk miskin dan terisolir secara geografis. Kehadiran LSM yang membantu korban banjir secara teknis cukup membantu tetapi disisi lain mendorong terjadinya ketidakpedulian serta ketergantungan terhadap bantuan pihak luar.
\end{abstract}

Kata kunci : kapital sosial, bencana banjir, ketahanan sosial

\begin{abstract}
Flood disaster oftenly beset Kabupaten Bandung region, West Java. Several flood disaster management in the region has been attempted, both in terms of technical handling such as river normalization and social handling such as relocate the residents. However, these efforts have not succeed to prevent residents from flood disaster. This study identifies the factors of social capital in the community who lived in flood area and analyzing the role of NGOs in responding flood disasters in Kabupaten Bandung. The study was conducted through qualitative approach using method of interview, observation, and documentation in three villages that most suffered by floods in Kabupaten Bandung. Those villages are Bojongsoang, Dayeuh Kolot, and Bale Endah. The results reveal that there are various solidity of social capital in three villages due to characteristics differences of each community. Social resilience owned by Dayeuh Kolot and Andir whereas its society's structure is dominated by middle-class and educated people, so they are more independent and responsive when faced devastating floods. While people in Bojongsoang are relatively more dependent when flooding occurs due to many poor and geographically isolated people in the village. The presence of NGOs in dealing with floods is technically enough to help people, but on the other hand it encourages people's ignorance and dependence on outside aids.
\end{abstract}

Keywords: social capital, flood disaster, social resilience

\footnotetext{
${ }^{2}$. Prodi Sosiologi, Fakultas Ilmu Sosial dan Ilmu Politik, Universitas Padjadjaran bintarsih.sekarningrum@unpad.ac.id

${ }^{3}$. Prodi Sosiologi, Fakultas Ilmu Sosial dan Ilmu Politik, Universitas Padjadjaran yuzzsar@gmail.com
} 


\section{PENDAHULUAN}

Kabupaten Bandung merupakan kawasan yang paling sering terjadi banjir. Bencana banjir tersebut tidak hanya disebabkan faktor alam, tetapi juga dipengaruhi faktor sosial seperti terjadinya peningkatan jumlah penduduk yang kemudian memperlebar wilayah pemukiman sehingga tidak sejalan lagi dengan daya dukung lingkungan yang ada. Kawasan Kabupaten Bandung sendiri secara geografis dilalui tiga sungai besar yaitu Sungai Citarum, Citanduy dan Cisangkuy. Disaat musim penghujan muara pertemuan ketiga sungai tersebut meluap dan menggenangi pemukiman warga yang lokasinya semakin mendekati bantaran sungai. Konsentrasi penduduk yang padat di kawasan titik muara tiga anak sungai di Kabupaten Bandung menyebabkan mereka tidak bisa menghindar dari bencana banjir.

Berbagai upaya telah dilakukan pemerintah untuk mencegah warga terkena dampak banjir. Secara teknis, pemerintah daerah Kabupaten Bandung yang didukung oleh Pemerintah Provinsi Jawa Barat dan Pemerintah Pusat telah melakukan normalisasi sungai Citarum. Dasar sungai yang telah dangkal kemudian dikeruk untuk mengembalikan kedalaman sungai, sehingga diharapkan permukaan aliran sungai tidak terlalu meluap. Penanganan secara sosial pun telah dilakukan, seperti evakuasi dan relokasi pemukiman warga secara permanen agar terhindar dari luapan air sungai.

Tetapi berbagai upaya tersebut dalam realisasinya tidak sepenuhnya optimal menghindarkan masyarakat dari bencana banjir. Salah satu kendala utama diyakini berasal dari kondisi masyarakat itu sendiri. Peningkatan jumlah penduduk, kepadatan pemukiman dan sikap masyarakat terhadap bencana banjir diyakini memiliki relevansi terhadap keberhasilan programprogram pemerintah untuk menangani masalah banjir. Terlebih lagi status wilayah ketiga yang sebagian besar merupakan kawasan industri sehingga masyarakat memiliki ketergantungan secara ekonomi. Dan untuk mempertahankan kehidupannya tersebut mereka telah melakukan beradaptasi didalam menghadapi bencana banjir.

Salah satu strategi adaptasi untuk menghadapi banjir adalah membentuk kelompok-kelompok dalam masyarakat terutama di daerah rawan banjir yang bertujuan mengangani bencana banjir. Munculnya komunitas-komuitas yang memiliki kesadaran sosial ini menandakan berlakunya nilai-nilai bertahan hidup dan mengatasi masalah yang bertumpu pada kemandirian masyarakat itu sendiri. Sikap ini dapat dilihat sebagai suatu konsensus di antara masyarakat yang mempromosikan nilai-nilai dalam rangka mempertahankan kestabilan sistem sosial. Namun, tindakan untuk mempertahankan sistem yang sudah ada, terutama dalam konteks adaptasi dengan bencana banjir belum tentu sejalan dengan program-program pemerintah. Di sisi lain, keberadaan organisasi masyarakat sipil dan kelompok-kelompok masyarakat di kawasan terkena 
dampak banjir menunjukkan bahwa modal sosial dalam masyarakat masih terpelihara. Hal ini juga menunjukkan masih adanya kemauan masyarakat untuk bekerjasama demi mencapai tujuan bersama dalam rangka mengatasi dampak buruk dari bencana banjir.

Penelitian ini mengkaji modal sosial pada masyarakat yang terkena dampak banjir di Kabupaten Bandung. Terdapat dua aspek yang hendak dicapai dalam penelitian ini. Pertama, identifikasi nilai atau norma informal yang dimiliki bersama pada masyarakat yang terkena dampak banjir. Kedua, menganalisis hubungan dan peran organisasi masyarakat sipil (kelompok-kelompok sosial) dalam menata kelola masyarakat setempat untuk mengatasi bencana banjir. Studi ini bertujuan untuk melihat sejauhmana perubahan nilai-nilai modal sosial seperti kepercayaan (trust), nilai-nilai (value) dan jaringan sosial (social network) di masyarakat pada saat sebelum dan setelah terjadi bencana banjir.

\section{METODE PENELITIAN}

Penelitian ini menggunakan pendekatan kualitatif dengan model studi kasus. Metode studi kasus dapat menjelaskan fokus kajian secara mendalam mengenai persoalan banjir di suatu tempat. Penelitian ini membandingkan fenomena banjir yang terjadi di beberapa kecamatan di Kabupaten Bandung yaitu di Kecamatan Dayeuhkolot, Kecamatan Bojongsoang dan Kecamatan Baleendah).

Teknik pengumpulan data dilakukan melalui observasi, wawancara, diskusi kelompok terfokus dan studi dokumentasi. Aspek yang diobservasi meliputi kondisi alam di tiga kecamatan yang diteliti, kehidupan sosial ekonomi masyarakat, budaya (tradisi dan nilai) yang terbangun, struktur sosial masyarakat, dan bentuk modal sosial.

Aspek yang diperoleh melalui wawancara antara lain, nilai-nilai modal sosial yang tumbuh dan menguat sebelum dan sesudah bencana banjir, proses tumbuh dan hilangnya modal sosial di masyarakat serta relasi dan peran kelompok sosial yang menggorganisir masyarakat dalam mengatasi masalah banjir. Diskusi kelompok terfokus (FGD) dilakukan untuk mendapatkan informasi mengenai perkembangan modal sosial di tengah masyarakat baik di masa lalu maupun masa kini yang berubah akibat bencana banjir.

Informan penelitian ditentukan dengan menggunakan teknik purpossive dan snowball sampling dengan melihat karakteristik lokasi bencana banjir, terdiri atas : tokoh masyarakat pemerhati dan pengorganisir masyarakat dalam mengatasi masalah banjir (tokoh agama, tokoh Ormas, Ketua RT/RW), dan aparat pemerintahan bidang khusus yang mengatasi persoalan banjir di masyarakat (BPBD, Bappeda, Dinas Sosial, Dinas Kesehatan, Dinas Tata Ruang dan 
Pemukiman, Dinas Pengairan, Dinas Pertanian dan kehutanan, Balai Besar Wilayah Sungai Cikapundung, Kecamatan, Desa dan instansi terkait lainnya).

\section{KERANGKA KONSEP/TEORITIS}

\section{Modal Sosial dalam Kebencanaan}

Dalam rangka mengidentifikasi komponen modal sosial yang ada di masyarakat serta menganalisis peran Lembaga Swadaya Masyarakat (LSM) dalam menangani bencana banjir di Kabupaten Bandung, kajian ini menggunakan perspektif konsep modal sosial terutama yang terkait dengan masalah kebencanaan. Penanganan bencana di suatu wilayah yang ditempati penduduk memerlukan pemahaman tentang pola perilaku mereka dalam menghadapi bencana. Kemampuan masyarakat untuk mengatasi masalah-masalah yang ditimbulkan oleh bencana, baik itu masalah sosial maupun fisik, ditentukan oleh kualitas kohesivitas dan interaksi di antara warganya. Oleh karena itu, konsep modal sosial menjadi relevan dalam kajian ini.

Konsep modal sosial berawal dari ilmu ekonomi yang menganggap "kapital" seperti uang dan properti yang akan bertambah nilainya jika diinvestasikan. Demikian pula dengan "tindakan" di masyarakat yang akan mendatangkan kebaikan bersama baik sekarang maupun di masa depan jika ditanamkan secara positif. Modal sosial bermanfaat didalam upaya mengatasi masalah dalam masyarakat secara bersama dan merupakan sumber motivasi untuk mencapai peningkatan ekonomi suatu masyarakat atau bangsa (Durkheim, 1973). Karakteristik dari modal sosial adalah akumulasi tindakan individu maupun gabungan individu yang menghasilkan keuntungan dan dapat direproduksi (Bourdieu dalam Hauberer, 2011:35).

Modal sosial mengindikasikan adanya kondisi suatu komunitas yang kuat dengan solidaritas yang kokoh serta identitas yang terpelihara. Beberapa elemen yang menunjukkan adanya modal sosial yang baik antara lain kuatnya kepercayaan (trust), tingginya kohesivitas, kuatnya altruisme, gotong royong, jejaring dan kerjasama di antara anggota masyarakat. Elemen-elemen tersebut kemudian berkontribusi terhedap pemenuhan tujuan bersama seperti mewujudkan kepentingan masyarakat, meningkatkan partisipasi publik, menurunkan tingkat kekerasan atau konflik serta meningkatkan keharmonisan masyarakat.

Putnam (1993) menjelaskan bahwa modal sosial merupakan jaringan sosial dan kepercayaan yang memfasilitasi kerjasama dan koordinasi terciptanya keuntungan sosial. Pernyataan tersebut menekankan bahwa modal sosial memerlukan pengorganisasian kerja dan harapan antar warga masyarakat. Selanjutnya Fukuyama (1995) mengungkapkan pentingnya kemampuan masyarakat yang timbul dari adanya kepercayaan dalam sebuah komunitas. Hubungan yang tercipta serta norma-norma yang membentuk kualitas dan kuantitas hubungan sosial kemudian menjadi 
perekat sosial (social glue) yang menjaga kesatuan anggota masyarakat. Modal sosial merupakan hasil interaksi yang kemudian menciptakan tingkat kepercayaan yang tinggi di ranah individu sebagai akibat adanya relasi emosional dan pada ranah institusional terjadi akibat adanya kesamaan kepentingan, visi serta misi.

Dari berbagai definisi tersebut, modal sosial merupakan interaksi yang berkualitas, terjalin dalam waktu yang relatif lama dengan melibatkan sisi emosional antar warga yang kemudian mampu menumbuhkan kepercayaan (trust) dalam rangka mewujudkan tujuan bersama. Dari sifat dan karakteristiknya, modal sosial dapat diperlakukan sebagai sumberdaya yang dapat digunakan untuk kegiatan saat ini maupun masa depan. Kualitas modal sosial yang tinggi akan tercermin dari adanya gotong-royong, kerjasama dan suasana harmonis di dalam masyarakat. Sebaliknya, kualitas modal sosial yang rendah akan memunculkan sikap saling curiga, egoisme individu atau kelompok yang kuat serta mudah terjadi konflik.

Ridell (1997, dalam Suharto, 2010) mengungkapkan beberapa parameter modal sosial. Pertama, adanya kepercayaan yang terindikasi dari perilaku jujur, terciptanya keteraturan sosial dan kerjasama antar warga berdasarkan norma-norma yang berlaku. Kepercayaan dipandang sebagai syarat keharusan (necessary condition) dari terbentuk dan terbangunnya modal sosial yang kuat. Lin (2008) menambahkan kepercayaan (trust) terkait dengan sikap untuk tetap menjaga kesepakatan, tolong menolong, dan menghindari perilaku oportunistik. Kedua, norma-norma sosial yang mencakup pemahaman, nilai-nilai dan etika yang dijalankan bersama berdasarkan rujukan ajaran agama, tradisi, etika profesi dan sebagainya. Ketiga, jejaring atau infrastruktur dinamis jaringan kerjasama yang memfasilitasi komunikasi dan interaksi di masyarakat. Jejaring tersebut dapat berbentuk formal maupun informal.

Lin (2001) telah mengidentifikasi tiga sumber utama variabel eksogen untuk modal sosial, yakni: 1) posisi struktural seperti; posisi hirarki struktural tokoh dalam stratifikasi sosial, kekuatan dan proposisi posisi; (2) lokasi jaringan atau lokasi tokoh dalam jaringan yang menunjukkan fitur tertentu seperti ketertutupan atau keterbukaan; dan (3) tujuan tindakan (instrumental; misalnya untuk memperoleh kekayaan, listrik, atau reputasi, atau ekspresif; misalnya untuk mempertahankan kohesi, solidaritas, atau kesejahteraan.

\section{Keberfungsian Sosial Masyarakat di Kawasan Bencana}

Manusia sebagai mahluk sosial hidup berkelompok membentuk sistem sosial, karena manusia saling tergantung sama lain, membentuk jejaring kerja (network) untuk menjalin relasi sosial. Persamaan dan perbedaan mendorong terbentuknya norma-norma dan nilai-nilai agar 
hubungan teratur dan tertib dan akhirnya direkatkan oleh ikatan sosial yang disebut trust untuk menjamin koeksistensi dalam struktur sosial yang lebih luas (Nuryana, 2004:90).

Pada sistem sosial level individu atau keluarga, keberfungsian sosial termasuk pembentukan pola hidup untuk memenuhi kebutuhan dasarnya, membangun hubungan positif didalam pengembangan pribadi serta penyesuaiannya. Individu senantiasa mencari dukungan pertolongan dari sistem sosial untuk keberfungsian sosial mereka. Pada level kelompok, organisasi, komunitas yaitu dengan memperbesar atau memperkuat kemampuan mengembangkan sumber-sumber, menciptakan harmoni diantara anggota mereka serta menciptakan kesempatan dinamis bagi pertumbuhan dan perubahan. Sumber untuk mengembangkan keberfungsian sosial tersebut dapat terletak di dalam sistem tersebut atau terletak pada struktur sosial lainnya.

Menurut Nuryana (2004:91-93), terdapat tiga tipe keberfungsian sosial yaitu adaptive, at risk dan maladaptive. Keberfungsian sosial adaptif mampu memaksimalkan sumber-sumber baik individu, kelompok serta kelembagaan untuk mengatasi permasalahan. Berbagai sumber tersebut relatif tersedia dan terjangkau oleh sistem tersebut. Sistem adaptif mampu menghadapi masalah serta mengambil langkah-langkah untuk mencari solusinya. Dalam beberapa literatur, sistem sosial yang adaptif dikenal sebagai masyarakat yang responsif (responsive community). Keberfungsian sosial yang beresiko (at risk social functioning) dimana sistem sosial kemungkinan mengalami kesulitan di dalam keberfungsian sosialnya. Hal ini menyebabkan masyarakat berada dalam kerentanan meskipun masalah yang ada belum muncul ke permukaan. Dengan kata lain, terdapat kondisi-kondisi tertentu yang diperkirakan berdampak terhadap keberfungsian sosial seperti pengangguran, hidup di pengungsian, konflik antar kelompok. Keberfungsian sosial maladaptif terjadi ketika sistem sosial semakin melemah atau mengalami stagnasi, sehingga tidak mampu menciptakan perubahan sosial. Terdapat masalah yang serius dalam sistem, sehingga kemudian menurunkan kemampuan sistem untuk melakukan adaptasi. Masalah tersebut seperti konflik sosial, depresi dan eksklusi sosial.

Keberfungsian sosial dari sistem sosial dapat berbeda atau berubah karena dipengaruhi oleh masalah-masalah sosial. Perubahan negatif atas keberfungsian sistem sosial dapat mengancam ketahanan sosial masyarakat. Oleh karena itu, sebuah realita apabila di lapangan ditemukan sistem sosial dengan berbagai tipe keberfungsian sosial. Namun semua pihak menginginkan agar keberfungsian sosial adaptif dapat berkembang secara dinamis, sehingga modal sosial yang dimiliki komunitas atau lembaga dapat berkembang secara dinamis. Sistem sosial yang didukung oleh modal sosial yang kuat diharapkan dapat memberikan kontribusi terhadap pengembangan ketahanan sosial masyarakat yang dinamis. Ketahanan sosial merpakan kemampuan komunitas 
atau lembaga didalam mengembangkan keberfungsian sosial secara dinamis dari modal sosial yang dimilikinya serta mampu memberikan perlindungan bagi kelompok rentan, memberikan dukungan bagi kelompok tidak mampu, mampu mengembangkan partisipasi politik anggota, mengelola konflik serta melestarikan sumberdaya yang ada (Nuryana, 2004:99).

\section{PEMBAHASAN}

\section{Karakteristik Bencana Banjir di Kabupaten Bandung}

Kontur topografis wilayah Bandung berada di antara bukit-bukit dan gunung-gunung yang memiliki aliran sungai utama, yakni Sungai Citarum dan anak-anak sungai yang bermuara ke Sungai Citarum tersebut. Jumlah penduduk Kabupaten Bandung tahun 2016 adalah 3.534.114 jiwa (pusdalisbang.jabarprov.go.id). Dari 31 Kecamatan yang ada di Kabupaten Bandung, terdapat tiga kecamatan rawan banjir yaitu Kecamatan Baleendah, Kecamatan Dayeuhkolot, dan Kecamatan Bojongsoang yang ketiganya saling berdekatan dan berada di daerah aliran Sungai Citarum.

Merujuk pada lokasi penelitian, wilayah rawan banjir berada di sekitar kawasan industri yaitu di Kecamatan Baleendah (terdapat 5 Industri besar dan 10 industri menengah); Kecamatan Dayeuhkolot (terdapat 38 industri besar dan 43 industri menengah), dan Kecamatan Bojong Soang (4 industri besar dan 21 industri menengah). Hal ini mengindikasikan bahwa wilayah rawan banjir di Kabupaten Bandung berada pada kawasan aglomerasi manusia yang terkumpul karena adanya aktivitas industri di wilayah-wilayah tersebut. Sebagai area aglomerasi manusia, di lokasi tersebut berhimpun sejumlah manusia yang mengelompok dan berupaya menangani banjir yang terjadi secara terorganisir.

Berdasarkan kajian karakter DAS Citarum (2011), 94\% (879,8 ha) wilayah Dayeuhkolot berpotensi terkena banjir setiap tahun. Wilayah ini termasuk DAS Citarum bagian hulu ${ }^{1}$ Terdapat dua wilayah yang terkena banjir untuk Kecamatan Baleendah yaitu Kelurahan Andir dan Kelurahan Baleendah. Berdasarkan data BNPB, di Kelurahan Andir banjir menggenangi 2.421 rumah meliputi $2.690 \mathrm{KK}$ (10.577 jiwa), sedangkan di Kelurahan Baleendah menggenangi 940 rumah, meliputi 879 KK (2.562 jiwa). Di Kecamatan Dayeuhkolot, banjir menggenangi empat desa, yaitu, Desa Dayeuhkolot, Cangkuang Wetan, Pasawahan, dan Citeureup, dengan jumlah rumah terendam $930 \mathrm{KK}$ (2.273 jiwa). Sedangkan di Kecamatan Bojongsoang, banjir terjadi di Kampung Cijagra yang menggenangi 564 rumah dan berdampak pada 564 KK (1.602

\footnotetext{
${ }^{1}$ http://daerah.sindonews.com/read/2013/03/27/21/731838/banjir-di-bandung-selatan-6-474-kk-terpaksamengungsi
}

107 | SUSIOGLLBAL : Jurnal Pemikiran dan Penelitian Sasiologi, Vol. I, No. 2, Juni 2017 
jiwa). Di Kecamatan Majalaya, banjir menggenangi 476 rumah yang terdiri dari 490 KK (1.892 jiwa).

Banjir di Kabupaten Bandung adalah bencana yang telah terjadi lebih dari tiga dekade lalu dan semakin besar potensinya jika terjadi hujan dengan intensitas sangat tinggi. Sejarah mencatat banjir besar pertama kali terjadi pada tahun 1986. Kejadian banjir yang terjadi pada tahun 1986 tersebut menggenangi 10 desa di 10 kecamatan. Tujuh kecamatan di antaranya Baleendah, Buahbatu, Dayeuhkolot, Majalaya, Rancaekek, Banjaran dan Pameungpeuk. Dampak yang ditimbulkan sebanyak 68.635 jiwa menderita dan 38.672 mengungsi serta terdapat 5 korban tewas ${ }^{2}$.

Saat ini banjir kerap terjadi meskipun telah dilakukan langkah-langkah pencegahan oleh pemerintah dan masyarakat. Beberapa upaya yang telah dilakukan oleh pemerintah dalam mengantisipasi banjir dengan melakukan normalisasi sungai, diantaranya pelebaran dan pengerukan sungai, relokasi jembatan Citarum yang menghubungkan Bojongsoang dengan Baleendah, pengerukan Citarum antara Baleendah dan Dayeuhkolot, meninggikan tanggul di sekitar Desa Andir Kecamatan Dayeuhkolot, dan membuat sodetan Citarum di beberapa tempat.

Meskipun upaya-upaya memperlancar arus aliran Sungai Citarum tersebut terus dilakukan, di lain sisi upaya-upaya tersebut tidak diimbangi dengan upaya menjaga lingkungan sekitar bantaran sungai untuk terbebas dari bangunan atau pemukiman penduduk. Selain itu, upaya normalisasi tidak didukung dengan sistem pemanfaatan lahan penunjang di sekitar daerah aliran Sungai Citarum. Hasil penelitian yang dilakukan mengungkapkan bahwa pada tahun 2010, terjadi perubahan di sekitar kawasan Citarum seperti; perubahan penggunaan lahan, meningkatnya volume sampah dan limbah, tanah longsor akibat perubahan penggunaan lahan, dan beroperasinya pabrik-pabrik di wilayah serapan air. Pemerintah melakukan program yang dipandang menjadi solusi mengatasi masalah banjir, yakni membangun rumah susun sewa sebagai upaya merelokasi sementara masyarakat yang tinggal di kawasan paling rentan terkena dampak banjir. Jika banjir telah surut, pengungsi kembali ke tempat tinggal masing-masing.

Hambatan dalam upaya penanganan banjir di Kabupaten Bandung tidak dapat dilepaskan dari kebijakan pemerintah sendiri. Kebijakan pemerintah mengenai tata ruang, pada satu sisi menjadi penghambat dalam upaya penanganan banjir di Kabupaten Bandung. Rencana tata ruang wilayah adalah suatu rencana yang harus bersesuaian dengan rencana detail nasional, sehingga

\footnotetext{
2 Dadang Bainur dalam Harian Pikiran Rakyat, Selasa 09 Desember 2008 http://www.dishut.jabarprov.go.id/?mod=detilSorotan\&idMenuKiri=345\&idSorotan=99.
} 
untuk menetapkan rencana tata ruang wilayah kabupaten atau kota harus sesuai dengan rencana tata ruang wilayah provinsi dan rencana tata ruang wilayah nasional. Rencana tata ruang Kabupaten bandung tidak secara spesifik mengatur mengenai rencana aksi penanggulangan banjir, hal ini dapat dilihat pada Keputusan Menteri Pekerjaan Umum No 20 tahun 2012. Dalam keputusan tersebut belum secara rinci tergambarkan mengenai daerah-daerah yang rawan bencana, sehinga belum dapat diberikan batasan-batasan dan rencana detail mengenai penanganan banjir tersebut. Oleh karena rencana detail tata ruang tersebut belum dapat diselesaikan, hal ini tentu saja menghambat proses perencanaan yang berdampak pada semakin sulitnya menangani banjir. Salah satu hal yang seharusnya dapat ditetapkan segera untuk menghindari dampak yang lebih luas dari terjadinya banjir adalah merencanakan zonasi peruntukan wilayah. Dengan adanya kepastian zonasi ini tentunya akan memudahkan pemerintah daerah untuk menata wilayahnya.

\section{Perubahan Modal Sosial Sebelum dan Setelah Bencana Banjir}

Banjir di Kabupaten Bandung telah menimbulkan perubahan baik fisik maupun non fisik. Perubahan fisik tampak pada dampak yang ditimbulkan akibat banjir seperti perubahan pada konstruksi rumah. Masyarakat mengembangkan pola adaptasi untuk menghadapi ancaman banjir dengan membuat konstruksi rumah dua lantai bagi yang mampu, sementara bagi keluarga yang kurang mampu membuat atap (parako) untuk menyimpan barang-barang yang dianggap penting. Pola adaptasi tersebut menjadi strategi survivalitas untuk kembali menghadapi banjir di masa yang akan datang. Hal ini terkait dengan keengganan masyarakat untuk pindah ke tempat lain atau direlokasi oleh pihak pemerintah. Keengganan tersebut disebabkan akan terganggunya kehidupan sosial ekonomi yang telah mapan di tempat asal yang belum ditentu terjamin di tempat yang baru nantinya.

Selanjutnya perubahan non fisik tampak pada perubahan kepercayaan, norma dan interaksi sosial. Banjir yang terjadi di Kabupaten Bandung menunjukkan adanya perubahan kepercayaan dari kondisi sebelum dengan sesudah bencana banjir. Kepercayaan ini dapat dilihat terutama pada saat bencana terjadi, masyarakat yang terkena bencana secara bersama-sama saling menjaga harta benda mereka untuk menghindari masuknya orang yang berniat untuk memanfaatkan kondisi bencana tersebut demi keuntungan pribadi. Kepercayaan juga dapat terlihat dari proses pendistribusian bantuan logistik kepada masyarakat yaitu berupa makanan, pakaian, selimut, alat masak, tenda, obat-obatan. Situasi tersebut tidak menimbulkan konflik diantara warga yang terkena bencana. Mekanisme yang dilakukan adalah melalui pendistribusian secara bertahap mulai dari Dinas Sosial sampai di tingkat desa, sehingga memudahkan proses pendistribusian.

109 | SGSIOGLLBAL : Jurnal Pemikiran dan Penelitian Sasiologi, Vol. I, №. 2, Juni 2017 
Keterlibatan pihak lain yang akan memberikan bantuan kepada masyarakat yang terkena bencana, menimbulkan sikap yang semakin terbuka terhadap pihak luar.

Dikaji dari perubahan norma, terjadi perubahan dari kondisi sebelum dengan sesudah banjir. Kegiatan membersihkan sisa banjir yang biasanya dilakukan secara bersama dalam bentuk kegiatan gotong royong, kini dilakukan secara masing-masing. Namun nilai gotong royong masih berlaku terutama pada lokasi pemukiman yang relatif jauh. Selain itu, dampak yang terjadi dari evakuasi korban bencana ke fasilitas kebencanaan yaitu Rusunawa menimbulkan menurunnya norma gotong royong diantara warga. Masyarakat beranggapan bahwa tugas menjaga kebersihan sungai dan merawat lingkungan bukan lagi menjadi tanggung jawab warga, karena sudah ada pemerintah yang secara rutin melakukan upaya pengerukan untuk mencegah terjadinya luapan air hujan ke permukiman masyarakat.

Berkaitan dengan interaksi sosial diantara warga baik di level mikro, meso maupun makro, banjir telah memunculkan gerakan sosial di tingkat akar rumput yaitu munculnya komunitas lokal. Komunitas lokal merupakan simpul (node) yang secara horisontal menghubungkan gerakan di antara warga lokal dan di saat yang sama secara vertikal menjadi penghubung antara warga lokal dengan pemerintah. Komunitas lokal berupaya untuk membangun kesadaran warga agar berjuang dengan membangun serta memperkokoh jejaring diantara warga sendiri. Hal ini ditandai dengan mulai munculnya komunitas lokal yang serupa di wilayah lainnya.

Selanjutnya relasi dan peran organisasi masyarakat dalam mengorganisir masyarakat untuk mengatasi banjir telah mulai terjalin, baik diantara organisasi masyarakat sipil maupun organisasi pemerintah. Terdapat beberapa organisasi masyarakat sipil yang berperan aktif dalam penanggulangan banjir di Kabupaten Bandung seperti : B2C2, Aksi Cepat Tanggap (ACT), Wahana Lingkungan Hidup (Walhi), Forum Komunikasi Putra Putri Purnawirawan TNI dan Polisi (FKPPI), Tim Peduli Citarum (TPC). Komunitas tersebut berperan selain memberikan bantuan terhadap korban juga memberikan penyuluhan dan pelatihan kepada masyarakat tentang penanggulangan bencana. Sementara itu, pihak pemerintah khususnya Dinas Sosial Kabupaten Bandung membentuk Taruna Siaga Bencana (Tagana) untuk menanggulangi bencana banjir dengan melakukan koordinasi dengan komunitas lokal yang ada di wilayah tersebut.

Berdasarkan kajian dari modal sosial pada bencana banjir di Kabupaten Bandung, menunjukkan adanya modal sosial yang tinggi dan ada pula modal sosial yang rendah. Modal sosial tinggi ditunjukkan oleh adanya kerjasama diantara warga masyarakat ketika terjadi bencana banjir. Situasi tersebut terjadi khusunya pada masyarakat yang belum memiliki komunitas lokal dan 
kurang memperoleh bantuan dari pihak luar. Sementara itu, modal sosial rendah ditunjukkan dengan adanya rasa saling curiga diantara warga masyarakat ketika memperoleh bantuan dari pihak luar.

Tabel 1. Perubahan Modal Sosial Sebelum dan Sesudah Bencana Banjir

\begin{tabular}{|c|c|c|c|}
\hline $\begin{array}{c}\text { Dimensi } \\
\text { Modal Sosial }\end{array}$ & $\begin{array}{c}\text { Kondisi } \\
\text { Sebelum Baniir }\end{array}$ & $\begin{array}{c}\text { Kondisi } \\
\text { Sesudah Baniir }\end{array}$ & $\begin{array}{l}\text { Temuan } \\
\text { Penelitian }\end{array}$ \\
\hline \multirow[t]{3}{*}{ Kepercayaan } & $\begin{array}{l}\text { Kepercayaan diantara } \\
\text { warga cukup baik }\end{array}$ & $\begin{array}{l}\text { Kepercayaan diantara } \\
\text { warga cukup baik }\end{array}$ & $\begin{array}{l}\text { Terjadi kasus kehilangan } \\
\text { barang }\end{array}$ \\
\hline & $\begin{array}{l}\text { Adanya prasangka buruk } \\
\text { terhadap kelompok } \\
\text { sosial tertentu di luar } \\
\text { lingkungannya }\end{array}$ & $\begin{array}{l}\text { Adanya prasangka baik } \\
\text { dan buruk terhadap } \\
\text { besaran bantuan yang } \\
\text { diberikan dan kepada } \\
\text { orang-orang yang menjadi } \\
\text { relawan }\end{array}$ & $\begin{array}{l}\text { Ada kepentingan } \\
\text { tertentu dibalik bantuan } \\
\text { untuk korban banjir }\end{array}$ \\
\hline & $\begin{array}{l}\text { Kepercayaan terhadap } \\
\text { pemerintah cukup baik }\end{array}$ & $\begin{array}{l}\text { Kepercayaan terhadap } \\
\text { pemerintah menurun, } \\
\text { ditandai adanya protes } \\
\text { ketika bantuan terlambat }\end{array}$ & $\begin{array}{l}\text { Masyarakat mulai kritis } \\
\text { dan menginginkan } \\
\text { adanya transparansi } \\
\text { dalam pemberian } \\
\text { bantuan }\end{array}$ \\
\hline \multirow[t]{6}{*}{ Norma } & $\begin{array}{l}\text { Rasa solidaritas sosial/ } \\
\text { kebersamaan masih ada }\end{array}$ & $\begin{array}{l}\text { Rasa solidaritas sosial } \\
\text { menurun }\end{array}$ & $\begin{array}{l}\text { Kebersamaam menjadi } \\
\text { berkurang setelah } \\
\text { adanya rumah } \\
\text { penampungan }\end{array}$ \\
\hline & $\begin{array}{l}\text { Masyarakat belum } \\
\text { memiliki kesiapan dalam } \\
\text { penanggulangan banjir }\end{array}$ & $\begin{array}{l}\text { Masyarakat memiliki } \\
\text { kesiapan dalam } \\
\text { menghadapi banjir }\end{array}$ & $\begin{array}{l}\text { Masyarakat beradaptasi } \\
\text { terhadap banjir, } \\
\text { sehingga terbentuk } \\
\text { "ketahanan sosial" }\end{array}$ \\
\hline & $\begin{array}{l}\text { Masyarakat melakukan } \\
\text { antisipasi banjir }\end{array}$ & $\begin{array}{l}\text { Masyarakat tidak mau } \\
\text { direlokasi }\end{array}$ & $\begin{array}{l}\text { Masyarakat tetap } \\
\text { bertahan di lokasi banjir }\end{array}$ \\
\hline & $\begin{array}{l}\text { Kesadaran dan } \\
\text { pemahaman (sense of } \\
\text { awareness) terhadap banjir } \\
\text { merupakan hal yang luar } \\
\text { biasa }\end{array}$ & $\begin{array}{l}\text { Kesadaran dan } \\
\text { pemahaman (awareness) } \\
\text { terhadap baniir } \\
\text { merupakan hal yang biasa }\end{array}$ & \\
\hline & $\begin{array}{l}\text { Keterikatan (sense of } \\
\text { belonging) terhadap tanah } \\
\text { kelahiran tinggi }\end{array}$ & $\begin{array}{l}\text { Keterikatan terhadap } \\
\text { tanah kelahiran tetap } \\
\text { tinggi }\end{array}$ & \\
\hline & $\begin{array}{l}\text { Keterlibatan masyarakat } \\
\text { dalam kegiatan preventif } \\
\text { banjir dan pembangunan } \\
\text { di lingkungan tempat } \\
\text { tinggal masih kuat }\end{array}$ & $\begin{array}{l}\text { Keterlibatan masyarakat } \\
\text { dalam kegiatan preventif } \\
\text { banjir dan pembangunan } \\
\text { di lingkungan tempat } \\
\text { tinggal mulai berkurang }\end{array}$ & $\begin{array}{l}\text { Adanya ketergantungan } \\
\text { terhadap bantuan dari } \\
\text { pihak luar }\end{array}$ \\
\hline \multirow[t]{2}{*}{ Jaringan } & $\begin{array}{l}\text { Belum terbentuk } \\
\text { komunitas lokal pada } \\
\text { saat terjadi banjir }\end{array}$ & $\begin{array}{l}\text { Terbentuknya komunitas } \\
\text { lokal }\end{array}$ & $\begin{array}{l}\text { Komunitas lokal bekerja } \\
\text { dengan pihak } \\
\text { pemerintah }\end{array}$ \\
\hline & $\begin{array}{l}\text { Terbentuknya Taruna } \\
\text { Siaga Bencana (Tagana) } \\
\text { oleh Dinas Sosial. }\end{array}$ & $\begin{array}{l}\text { Taruna Siaga Bencana } \\
\text { (Tagana) melaksanakan } \\
\text { tugas sesuai Tupoksi }\end{array}$ & $\begin{array}{l}\text { Terbentuk komunitas } \\
\text { lokal di wilayah lain }\end{array}$ \\
\hline
\end{tabular}

Sumber : diolah dari hasil penelitian, 2013 


\section{Keberfungsian Sosial Masyarakat di Kawasan Bencana di Kabupaten Bandung}

Menurut Nuryana (2004), modal sosial terkait dengan keberfungsian sosial di dalam sistem sosial. Keberfungsian sosial tersebut dapat bersifat adaptif, at risk dan maladaptif. Beberapa nilai modal sosial yang menguat di dalam masyarakat yang terkena bencana banjir menunjukan keberfungsian sosial adaptif. Masyarakat berusaha melakukan upaya adaptasi terhadap kondisi banjir yang rutin terjadi. Proses adaptasi dilakukan karena mereka tidak ingin direlokasi, mengingat jika terjadi relokasi maka akan banyak sekali perubahan yang harus dilakukan oleh masyarakat jika ingin kembali mencapai titik kestabilan yang diinginkan.

Selanjutnya, upaya adaptif juga dilakukan untuk mempertahankan keberadaan mereka di lokasi bencana. Setiap program yang dikembangkan oleh banyak pihak di lokasi juga menunjukkan upaya untuk mempertahankan keberadaan masyarakat di lokasi bencana. Selain itu, pola-pola penanggulangan bencana yang dilakukan juga sebagai suatu upaya untuk tetap mempertahankan pola-pola yang selama ini telah berkembang di masyarakat. Dalam bentuk nyata, strategi adaptasi yang muncul dalam upaya mengantisipasi banjir diantaranya dengan membangun rumah dua lantai atau meninggikan atap rumah (parako), mengamankan barang-barang berharga ke lantai dua serta berbagi tugas jaga diantara relawan.

Keberfungsian sosial yang beresiko (at risk) dan maladaptif muncul di masyarakat dalam bentuk mengungsi ke luar wilayah atau ke rumah kerabat. Muncul sikap ketergantungan terhadap bantuan baik dari pihak LSM maupun pemerintah. Sebagian masyarakat melakukan aktivitas "ngencleng" untuk meminta bantuan di jalan raya. Hal ini menunjukan modal sosial yang ada telah mengalami pelemahan dan secara lebih jauh menunjukan adanya kerentanan sosial masyarakat.

Secara keseluruhan, output dari berkembangnya nilai-nilai modal sosial membentuk sebuah sistem untuk menanggulangi situasi banjir yang rutin terjadi. Banjir dilihat sebagai sistem yang dapat mengancam sustainabilitas sistem sosial. Oleh karena itu, masyarakat dalam kesatuannya terus membentuk kesetimbangan dengan cara beradaptasi atau melalui program pemerintah maupun komunitas yang terbangun. Modal sosial dilihat sebagai proses penyesuaian dari kesadaran kelompok-kelompok sosial yang dipilih untuk menjaga kesetimbangan agar tetap dapat beradaptasi, sehingga menjadi kebertahanan sosial ditengah masyarakat. Melalui integrasi kelompok-tersebut, masyarakat melakukan penyesuaian dengan membentuk nilai bersama yang baru sebagai suatu proses dan juga hasil strategi adaptasi terhadap kondisi lingkungan. 
Adanya kepercayaan diantara warga, melestarikan norma dan membangun jaringan tidak lain untuk mencapai tujuan agar masyarakat tetap dapat bertahan dengan kondisi yang ada untuk mempertahankan kelangsungan hidupnya. Dengan kata lain, melestarikan modal sosial memiliki tujuan yang jelas yaitu untuk mencapai ketahanan sosial. Ketahanan sosial akan tercapai apabila relasi antara warga maupun komunitas yang ada mengatur antar hubungan bagian-bagian yang menjadi komponennya dan pada akhirnya menumbuhkan suatu keyakinan akan harapan hidup meskipun akan menghadapi rutinitas banjir. Dalam kasus ini, modal sosial dapat melengkapi, memelihara dan memperbaiki motivasi individu maupun komunitas dalam mengatasi banjir.

\section{SIMPULAN}

Dimensi modal sosial yang muncul terkait dengan penanganan bencana banjir di Kabupaten Bandung muncul dalam bentuk kepercayaan (trust), norma dan jaringan sosial. Pada dimensi kepercayaan, sebelum terjadi bencana banjir, kepercayaan dalam masyarakat tertata dengan baik. Namun setelah berulang kali terjadi banjir, rasa saling percaya di antara masyarakat menjadi bersifat paradoks, tetap kuat namun adapula yang melemah. Sementara itu, kepercayaan terhadap pemerintah sebelum bencana banjir cukup baik, namun setelah terjadi banjir secara berulang, kepercayaan terhadap pemerintah cenderung turn. Hal ini disebabkan kecurigaan masyarakat terhadap pemerintah yang dipandang memanipulasi bantuan dan keterlambatan bantuan. Pada dimensi norma, kebersamaan masyarakat sebelum banjir cukup kuat. Namun setelah berdirinya kelompok-kelompok komunitas lokal non pemerintah (LSM) yang menangani bencana banjir, norma yang mengikat masyarakat cenderung pudar. Hal ini disebabkan masyarakat lebih bergantung kepada bantuan dari LSM dan pemerintah. Pada dimensi jaringan sosial, sebelum bencana banjir masyarakat belum membentuk jaringan sosial yang berfokus pada penanganan banjir. Setelah bencana banjir, mulai terbentuk komunitas lokal.

Relasi dan peran organisasi masyarakat dalam mengorganisir masyarakat untuk mengatasi banjir telah mulai terjalin, baik diantara organisasi masyarakat sipil maupun organisasi pemerintah dengan memberikan penyuluhan dan pelatihan kepada masyarakat tentang penanggulangan bencana banjir. 


\section{DAFTAR PUSTAKA}

Chodorov, Frank.1959.The Rise and Fall of Society An Essay on the Economic Forces That Underlie Social Institutions. The Devin-Adair Company:New York

Durkheim, E.1973.Moral Education: Study in the Theory and Application of the Sociology of Education.New York: Free Press.

Etzioni, Amitai.1996.The Good Society http://www.gwu.edu/ ccps/etzioni/A296.pdf [25/06/2013 10.00]

Fukuyama, F.1995.Trust: The Social Virtues and The Creation of Prosperity.New York:Free Press.

Grootaert, Christiaan.2004.Measuring Social Capital An Integrated Questionnaire. Washington, D.C:The World Bank

Hauberer, Julia.2010.Social Capital Theory Towards a Methodological Foundation.Dissertation Charles University in Prague

Kementerian Pekerjaan Umum Badan Penelitian dan Pengembangan Puslitbang Sosial Ekonomi dan Lingkungan. 2011. Executive Summary Uji Model Kelembagaan Sistem Peringatan Dini Banjir Debris Berbasis Masyarakat http://www.pu.go.id/uploads/services/infopublik20130502125704.pdf.

Nuryana, Mu'man.2004.Modal Sosial dalam Isu-isu Tematik Pembangunan Sosial : Konsepsi dan Strategi (Suharto, ed).Jakarta:Balitbangsos Depsos RI

Putnam, Robert D.1993.Making Democracy Work Civic Traditions in Modern Italy.New Jersey:Princeton University Press

Pusat Data dan Analisa Pembangunan Jawa Barat. (2017). Data Kependudukan. Diakses melalui http. http://pusdalisbang.jabarprov.go.id/pusdalisbang/data-94-Kependudukan.html, tanggal 7 Agustus 2017.

Rohmat, et.al (tanpa tahun). Keberadaan, Potensi dan Gagasan Pemanfaatan Sungai Mati di Sepanjang Sungai Citarum - daerah bandung http://www.citarum.org/upload/knowledge/document/Keberadaan_Potensi_Gagasan _Pemanfaatan_Sungai_Mati_di_Sepanjang_Sungai_Citarum.pdf. [25/06/2013 10:30 WIB]

Suharto, Edi.2010.CSR dan Comdev. Bandung : Alfabeta.

Suharto,Edi.2011.Kebijakan Sosial Sebagai Kebijakan Publik.Bandung : Alfabeta.

Supriono, et.al. (Tanpa tahun). Modal Sosial: Unsur-Unsur Pembentuk http://p2dtk.bappenas.go.id/downlot.php?file=Sosial\%20Capital,\%20Unsur-

Unsur\%20Pembentuk.pdf 